YEARBOOK

of ANTITRUST

and REGULATORY

STUDIES

www.yars.wz.uw.edu.pl
Peer-reviewed scientific periodical, focusing on legal and economic issues of antitrust and regulation. Creative Commons Attribution-No Derivative Works 3.0 Poland License.

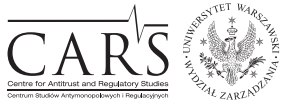

Centre for Antitrust and Regulatory Studies, University of Warsaw, Faculty of Management www.cars.wZ.uw.edu.pl

\title{
Can an Ideal Court Model in Private Antitrust Enforcement Be Established?
}

by

\author{
Dominik Wolski*
}

\section{CONTENTS}

I. Introduction

II. The American Model of Antitrust Litigation

III. Is the UK the hub for Antitrust Damage Claims?

IV. Antitrust Litigation in the Netherlands and Germany

1. The Netherlands

2. Germany

V. The Court Models operating in Other European States

1. Specialized and quasi-specialized courts
1.1. Portugal
1.2. Spain
1.3. Italy
1.4. France
1.5. Bulgaria
1.6. Croatia
1.7. Latvia
1.8. Lithuania
1.9. Romania
1.10. Slovakia
1.11. Slovenia

2. Ordinary courts

\subsection{Austria}

2.2. Czech Republic

2.3. Estonia

* PhD in law, Assistant Professor at Katowice School of Economics, attorney-at-law; e-mail: wolski_d@yahoo.pl. Article received: 10 August 2018; accepted 19 November 2018. 


\title{
2.4. Italy
}

2.5. Poland

VI. How Binding is the Effect and Judicial Review of NCAs Decisions in Adjudicating Antitrust Litigation? Can any Court Model really be considered an Ideal?

VII. Closing Remarks

\begin{abstract}
Any discussion of private antitrust enforcement usually focuses on substantive law and proceedings applicable to private antitrust cases. Those elements are important, however, the efficacy of both public and private enforcement relies upon rules of law (substantive and procedural) along with their application. The latter constitutes a substantial aspect affecting the institutions which make decisions in private antitrust enforcement cases, namely the relevant courts. The enforcement of competition law is inextricably intertwined with the economy and markets. As a result, antitrust cases are demanding for non-specialist judges, who usually do not have enough knowledge and experience in the field of competition. Even if the Damages Directive has already been implemented in all EU Member States, there is still room for discussion about developing an optimal court model for the adjudication of private antitrust enforcement cases. In the aforementioned discussion the issue of the binding effect of decisions made by the European Commission (EC) and National Competition Authorities (NCAs) in private enforcement cases, as well as the experience of judges stemming from the number of cases they have resolved, cannot be missed. Bearing this in mind, the main aim of this paper is to analyse the model of competent courts operating in private antitrust cases in twenty selected countries including the US, the UK and the vast majority of EU Member States. Taking into account that a theoretically pure concept of an ideal model of relevant court operations presumably does not exist, it is essential to try to figure out what the main characteristics of the courts might be that can lead to effective private antitrust enforcement.
\end{abstract}

\section{Résumé}

Toute discussion sur l'application privée du droit de la concurrence se concentre habituellement sur le droit matériel et sur les procédures applicables aux affaires antitrust privées. Ces éléments sont importants, cependant, l'efficacité de l'application publique et privée repose sur des règles de droit (matériel et procédural) ainsi que leur application. Ce dernier constitue un aspect important affectant les institutions qui prennent des décisions dans les cas d'application des lois antitrust privées, qui sont les tribunaux compétents. Lapplication du droit de la concurrence est inextricablement liée à l'économie et aux marchés. En conséquence, les affaires antitrust exigent des juges non spécialisés, qui n'ont généralement pas suffisamment de connaissances et d'expérience dans le domaine de la concurrence. 
Même si la directive 'dommages-intérêts' a été mise en œuvre dans tous les États membres de l'Union européenne, il reste encore des discussions sur la mise au point d'un modèle judiciaire optimal pour le règlement des affaires d'antitrust privées. Dans la discussion susmentionnée, la question de l'effet contraignant des décisions prises par la Commission européenne et par les autorités nationales de la concurrence dans les affaires privées, ainsi que l'expérience des juges découlant du nombre d'affaires résolues, ne peuvent manquer. Dans cet esprit, l'objectif principal de cet article est d'analyser le modèle des tribunaux compétents opérant dans les affaires antitrust privées dans vingt pays sélectionnés, y compris les États-Unis, le Royaume-Uni et la grande majorité des États membres. Puisqu'un concept théoriquement pur de modèle idéal d'activités judiciaires pertinentes n'existe pas, il est essentiel de tenter de déterminer quelles pourraient être les caractéristiques principales des tribunaux susceptibles de conduire à une application efficace des lois antitrust dans les affaires privées.

Key words: antitrust private enforcement; specialized, quasi-specialized and non-specialized courts; antitrust litigations; judges; jury; judicial review.

JEL: K21, K40

\section{Introduction}

Even though the Damages Directive (hereinafter; Directive) ${ }^{1}$ has already been implemented in all European Union (hereinafter; EU) Member States, ${ }^{2}$ this does not mean that discussions surrounding private antitrust enforcement triggered by the work preceding the Directive have come to an end. On the contrary, both in the US and the EU, a great number of academics and practitioners continue to discuss the rationale and efficacy of private antitrust enforcement models introduced in relevant States or organizations (like the EU). Some of them are of the opinion that the private enforcement model goes too far in imposing certain solutions, such as treble damages which can lead to over-deterrence (Jones, 1999, p. 80-81). Compensation fails because the actual economic victims are too numerous and remote from the violation, whereas deterrence is ineffective (Crane, 2010, p. 677). Therefore, the only

${ }^{1}$ Directive 2014/104/EU of the European Parliament and of the Council of 26 November 2014 on certain rules governing actions for damages under national law for infringements of competition law provisions of the Member States and of the European Union Text with EEA relevance.

2 See Member States' communication on the European Commission website: http:// ec.europa.eu/competition/antitrust/actionsdamages/directive_en.html 
way of effectively enforcing antitrust law is the public one (Wils, 2003, pp. 473-488). Those from the opposing camp claim that the treble damages rule effectively provides merely single damages. Consequently, they demand higher multipliers of damages to be adopted (Lande, 2004, p. 344; Lande, 2006, p. 6). This discussion seems to be never ending since interlocutors, proponents and opponents of a given model of private enforcement are not able to provide a definite and overriding argument, even if they reach for lofty concepts like consumer and social welfare or evoke empirical data (Lande and Davis, 2008).

The aforementioned discussion is very interesting in itself and very engaging, however, it mainly focuses on substantive law (for example rules of liability, quantification of damage, multiplier of damages, limitation periods, etc.) and proceedings (for instance disclosure of evidence, binding effect of NCAs' decisions, etc.). Even though those elements are of great importance, it should not be forgotten that the effectiveness of every type of enforcement, public as well as private, is the outcome of two key factors - rules of law (substantive and procedural) and their application. Therefore, even though the author of this paper is not about to question the time spent on analysing the rules which govern private enforcement, the model of court in the adjudication of antitrust litigations is also worth discussing.

Public antitrust proceedings are mostly pursued by various types of competition authorities, whereas bodies responsible for private antitrust enforcement are usually competent courts. The latter are in some cases specialized courts, but usually consist of generalist judges, and are therefore better or worse prepared to deal with competition-based cases. In these types of cases, law and economics are inseparable and specific training for judges, or as in the American jurisdiction also jurors, seems necessary. However, this either happens rarely or does not happen at all. The EU Member States decided to adopt various solutions ranging from ordinary civil courts to specialized courts in order to make decisions in private antitrust cases. Nonetheless we can learn from the following parts of this paper that even the notion of a 'specialized court' can be vague. Some of the countries involved, like the US, have long standing traditions of antitrust litigation, while some others, like most EU Member States, only recently began their serious adventure into the world of private antitrust enforcement. This means, in turn, that even if the directional decision has already been taken, there is still room for discussion of an optimal model of courts to adjudicate private antitrust cases. Furthermore, even though the Directive does not impose any particular solutions pertaining to the model of courts in private antitrust cases, this does not mean that its provisions are irrelevant. On the contrary - the binding effect of NCAs decisions, as well as guidelines regarding the quantification of harm, can significantly influence the 
decisions made by courts dealing with antitrust litigations. Therefore, those are also issues discussed in this paper to the relevant extent.

Bearing this in mind, the main aim of this paper is to analyse the model of courts in several countries, and its development, in order to discuss the optimal option for antitrust damages claims. If such a model exists, it could become a template to be implemented in countries which are determined to substantially boost their own private antitrust enforcement. This paper analyses the models used by courts in twenty countries. Even though this is not a fully comprehensive study in methodological terms (it does not cover all EU Member States), considering the quality of the research sample - the study includes the US and the biggest EU economies - the author believes that this allows him to achieve the main goals of this paper.

The analysis contained in this paper is limited by the sources which were accessible at the time of writing, their contents and quality of the information they contain. However, the author believes that the data presented in this paper allows us to draw credible conclusions with respect to the model of courts in private antitrust cases. The paper also covers, to the relevant extent, the binding effect of NCAs decisions as well as makes some observations on the judicial review of such decisions. The latter issue is particularly relevant when discussing the need for specialized or non-specialized courts to adjudicate antitrust litigations. This is because it can reasonably be assumed that the courts that review NCAs decisions have more experience and knowledge in competition matters. As a result, they have more capability in dealing with competition litigation too. Therefore, this issue is discussed in this paper in the context of the need for specialised or non-specialised court involvement in private antitrust cases. Furthermore, in the last part, the author considers whether the creation of an optimal model of court in antitrust cases is possible at all. The paper does not discuss arbitration as one of the potential alternatives for resolving antitrust disputes.

\section{The American Model of Antitrust Litigation}

The US litigation-oriented model of antitrust enforcement is unique (Jones, 1999, p. 19), being the birthplace of private antitrust enforcement with an overwhelming number of litigations ${ }^{3}-$ a factor which does not seem to be changing. Therefore this paper aims to start with a discussion of the US example. The structure of the authorities and courts competent in private

3 With a rough number of $90 \%$ of private and $10 \%$ of private enforcement proceedings (see i.a. Jones, 1999, p. 16). 
antitrust enforcement cases is complex. The complexity of the enforcement of US antitrust laws arises out of its decentralization (Jones, 1999, p. 14), as well as from the fact that enforcement is shared between various bodies at both State and Federal levels. Antitrust law in its private dimension is enforced by the Antitrust Division of the United States Department of Justice (hereinafter; DOJ), the Federal Trade Commission (hereinafter; FTC) and private individuals and entities, as well as the State Attorney General which can bring Federal antitrust suits on behalf of natural persons based on section $4 \mathrm{C}$ of the Clayton Act. ${ }^{4}$ In the latter case, the State Attorney General can bring cases on behalf of each State and other public entities or on behalf of its citizens ${ }^{5}$. Additionally, irrespective of Federal law, in most US States, the State Attorneys General can initiate actions based on the antitrust laws of individual States $^{6}$. The States themselves as well as, in some States, their Attorneys General, have also the authority to sue as parens patriae on behalf of State residents ${ }^{7}$. Generally, States hold parens patriae according to both Federal and State law, which empowers them to seek damages on their own behalf and on behalf of their citizens as consumers ${ }^{8}$. Regarding damages claims, the DOJ is empowered to bring civil actions in order to recover damages of the same type as a private individual or entity, should the United States government have been injured as a result of a violation (Sullivan and Hovenkamp, 2003, pp. 65-66; Sullivan and Grimes, 2006, pp. 930-931; Jones, 1999, p. 14).

According to section 4 of the Clayton Act, any person (individual, business, government), who has been injured as a result of an antitrust violation may sue to recover treble damages, costs of the legal action and Attorney fees (Sullivan and Hovenkamp, 2003, p. 70). Regarding the court of jurisdiction competent in antitrust litigations, sections 4 and 16 of the Clayton Act state that jurisdiction is exclusive to Federal district courts, officially titled the United States District Courts. These are the courts where most of private plaintiff complaints are filed initially (Hovenkamp, 2005, p. 343; Jones, 1999, p. 16; Saint-Antoine, Lewers, Hutchison, Bullard and Michelen, 2016). Antitrust cases are usually brought to a trial court, presided by a single judge; that judge or a jury composed of randomly chosen ordinary citizens makes the initial decision in the case. In civil cases, antitrust litigations included, each party (plaintiff as well as defendant) may require the resolution of the case by a jury. This rule follows the Seventh

4 Clayton Antitrust Act, 1914, c. 323, 38 Stat. 730 (see also Jones, 1999, pp. 14-16).

5 State Antitrust Enforcement Handbook, American Bar Association, 2018, p. 9.

${ }^{6}$ Ibidem, p. 15 and Jones, 1999, p. 16.

7 State Antitrust Enforcement..., p. 9 and p. 15. Some States can also empower other entities to bring civil State-law antitrust lawsuits. See Ibidem, p. 16.

8 The concept of parens patriae originally arises from English constitutional systems as a 'father of the country'. For more see State Antitrust Enforcement..., p. 25. 
Amendment to the Constitution of the United States preserving the right of trial by jury (Jones, 1999, p. 22). In a jury trial, the judge determines the law and gives the jury oral and written instructions how to apply the law to the factual circumstances of the case. The jury applies the law to the facts; its verdict must be unanimous. It is worth emphasising that neither judge nor jury have specific expert knowledge in economic matters - antitrust legislation included. The litigants usually have to teach jury members specific aspects required for them to make a competent decision. Moreover, in antitrust cases, expert witnesses, economists, accountants, etc., are very often appointed (Jones, 1999, p. 22). Bearing in mind the above mentioned characteristics of Federal district courts adjudicating the vast majority of antitrust cases, they should be perceived as non-specialized courts in the field of antitrust and its private enforcement.

A party unsatisfied with the decision of a district court can lodge an appeal to one of thirteen circuit courts of appeal, officially titled the United States Courts of Appeals. In case of a conflict between circuits, usually the Supreme Court decides. It is worth noting that Federal courts of appeal have no jurisdiction empowering them to review decisions issued by State courts (Broder, 2005, pp. 6-7; Jones, 1999, pp. 20-21). Finally, cases can be directed to the Supreme Court of the United States. This court, as the highest court in the US, exercises appellate jurisdiction over the thirteen Federal courts of appeal (Broder, 2005, pp. 6-7; Jones, 1999, p. 20; Saint-Antoine, Lewers, Hutchison, Bullard and Michelen, 2016). Additionally, in situations involving several more or less similar cases brought forward in different districts, the Judicial Panel on Multidistrict Litigation can decide on the consolidation of such cases before a single court (Broder, 2005, pp. 6-7; Saint-Antoine, Lewers, Hutchison, Bullard and Michelen, 2016).

Regarding further issues relating to the interplay between the Federal and State enforcement level, it is worth noting that it has been held that a prior State decision may operate as a bar to subsequent Federal antitrust claims, and that subsequent Federal antitrust courts should consider the preclusive effect of a prior State judgement with regard to the preclusion law of the State court (Sullivan and Hovenkamp, 2003, p. 72; Sullivan and Grimes, 2006, pp. 946 and 949) $)^{9}$. Furthermore, there is also an interesting development of inter-State commerce theory analysed in several meaningful judgements, starting with E.C. Knight Co., 156 U.S. 1, 12 (1985) (Sullivan and Hovenkamp, 2003, pp. 77-78). The nitty gritty of the discussion is that a Federal antitrust law-based claim can be brought only if the conduct in question has the form of inter-State commerce, or one that affects such commerce (Sullivan and Grimes, 2006, p. 983).

\footnotetext{
9 See also Marrese v. American Academy of Orthopedic Surgeons, 47 U.S. 373 (1985).
} 
As mentioned above, US courts dealing with antitrust damages claims are ordinary courts competent to deal with cases other than antitrust too. These are non-specialized courts deciding in antitrust matters, even if their record of antitrust cases is striking. Therefore, even having experience in dealing with antitrust cases, neither judges nor juries are specialists in the fields of the economy or, in particular, in competition law. Bearing this in mind, it is worth noting that Federal agencies (as the key enforcers) have substantial impact upon the development of the law, setting guidelines for Federal and State courts, State enforcement officials, private litigants and attorneys. This is because Federal agencies have brought many ground breaking cases in this field (Sullivan and Grimes, 2006, p. 930). As a result, courts resolving antitrust litigations, even if non-specialized, take guidance from the practice of Federal enforcement agencies. Notwithstanding the foregoing, the Antitrust Division of the DOJ occasionally can file an amicus brief to the Federal courts, which is, however, likely to happen when the case reaches the Supreme Court (Sullivan and Grimes, 2006, p. 932). It is also worth mentioning that while a well-developed and resulting in great awards for the winning plaintiffs, the costs of the US non-specialized-model of antitrust litigations are high with respect of both time and money (Gotts, 2018, p. vii).

\section{Is the UK the Hub for Antitrust Damages Claims?}

The UK, Germany and the Netherlands are becoming the main 'hubs' for antitrust litigations in Europe (Gotts, 2018, p. viii). This does not mean that the venues accessible to plaintiffs are centred on those countries. Since the British model of courts competent in antitrust cases has its specificity and significantly differs from the others, it is discussed separately. From this perspective it is worth noting that over the last years, there has been an explosion of cartel damage litigations in British courts (Robertson, 2017, p. 2). The accumulation of antitrust litigations may also result from a demonstrable willingness of British courts to deal with cases that have sometimes only a small connection with the UK jurisdiction. This means, in turn, that in practice UK courts usually find themselves competent if the claimant proves successfully the concept of a so-called 'anchor defendant', namely a company domiciled in the UK. This relates in particular to cartel cases where it is enough in order to obtain UK jurisdiction to find that at least one company from the cartelists is domiciled within the UK territory (Gelmini, 2017, p. 3).

The current model of courts which deal with antitrust damages actions in the UK, which has been in existence since 1 October 2015, was established by 
the amendments to the Competition Act $1998^{10}$ introduced by the Consumer Rights Act 201511. As a result, there are two courts competent in antitrust litigations, namely the High Court (hereinafter; HC) and the Competition Appeal Tribunal (hereinafter; CAT). Therefore, both types of actions, standalone and follow-on, can be brought to either the HC or the CAT. However, whereas the $\mathrm{HC}$ has jurisdiction over England and Wales only, the CAT's jurisdiction extends across the entire UK (Adkins and Beighton, 2016, p. 1; Slaughter and May, 2017, p. 4). Private antitrust actions can also be transferred between the courts (the $\mathrm{HC}$ and the CAT) within the discretion of the relevant forum (Adkins and Beighton, 2016, p. 13). Regarding the HC, antitrust litigations are heard by either the Chancery Division or the Commercial Court of the Queen's Bench Division (Adkins and Beighton, 2016, p. 2). Considering the need for specialized and non-specialized courts in antitrust cases, the most important aspect of antitrust litigations is the composition of the court. When adjudicating, the $\mathrm{HC}$ usually consists of a single judge who is a lawyer (normally a barrister) (Slaughter and May, 2017, p. 5). As a result, the $\mathrm{HC}$ seems to have a traditional, legalistic approach in terms of competences and training required from persons who decide in private antitrust cases. With regards to the acceleration of private enforcement actions in British courts, this trend has been observed in the $\mathrm{HC}$ as well, where the number of cases has increased significantly ${ }^{12}$. In relation to the possibility of challenging a judgement issued by the $\mathrm{HC}$, if a party to the proceedings is unsatisfied with the judgement, it can lodge an appeal based on fact or law to the Court of Appeal. Furthermore, in cases of general public importance, there is the possibility of filing an appeal from the Court of Appeal to the Supreme Court (Adkins and Beighton, 2016, p. 41).

The CAT was established by Section 12 and Schedule 2 to the Enterprise Act $2002^{13}$, which came into force on 1 April 2003 - however, its role significantly increased once the constrains placed previously on pursuing stand-alone actions were repealed, as a result of the reform implemented by the Consumer Rights Act 2015. Therefore, having no intention to undermine the significant role of the $\mathrm{HC}$ in private antitrust enforcement, there remains the unquestionable fact that the CAT is becoming the most popular venue for antitrust litigations. The number of cases being brought to the CAT has been increasing, not to mention some cases that are transferred from the HC to the CAT, additionally enlarging this number. This trend does not seem likely to change in the future,

10 http://www.legislation.gov.uk/ukpga/1998/41/contents.

11 http://www.legislation.gov.uk/ukpga/2015/15/contents/enacted. See also Adkins and Beighton, 2016, p. 1.

12 Competition Appeal Tribunal, Annual Report and Accounts 2016/2017, p. 13.

13 https://www.legislation.gov.uk/ukpga/2002/40/contents. 
since if any party pursues monetary compensation (damages or sum of money) in any part of the UK, the claim can usually be brought before the CAT. ${ }^{14}$ Therefore, the number of antitrust litigations before the CAT - actually only a part of the CAT's jurisdiction ${ }^{15}$ - is expected to continue to grow ${ }^{16}$. It is also worth mentioning that despite many procedural similarities between the aforementioned venues, there are some significant differences too. One of the important differences is the less legalistic and more flexible approach of the CAT to resolving antitrust damages claims.

As this paper is mainly, even if not entirely, focused on the role of courts in antitrust litigations, one of its most important aspects is the composition of the court dealing with litigations. In the case of the CAT, this is the outstanding feature in comparison to other models of courts discussed in this paper. Antitrust claims are heard in the CAT by a panel of three people consisting of one person who is a lawyer (the chairman of the tribunal) and other two non-lawyers (ordinary members). Those people are chosen from a list of experts from fields such as economics, accountancy, business and other competition and market-related fields ${ }^{17}$. The important role of the experts involved in resolving antitrust litigations, who have an equal voice with the chairman when deciding about the case ${ }^{18}$, is very often emphasised as the CAT's distinctive feature. This element distinguishes the CAT from other courts hearing antitrust cases, the HC included. This is also the main reason why the CAT is perceived as a specific, specialized body particularly competent in competition litigations with a remarkable record of cases resolved. Please see the official website of the UK government: 'The UK Competition Appeal Tribunal (CAT) is a specialist judicial body with a cross-disciplinary expertise in law, economics, business and accountancy, whose function is to hear and decide cases involving competition or economic regulatory issues' 19 .

Considering the aforementioned characteristics of the CAT in the context of an ideal model of court dealing with antitrust damages claims, a few issues are worth drawing attention too. There is a lot of enthusiasm surrounding the CAT and its role as the major venue for private enforcement of competition law in the UK. The decision of the UK government on the creation the CAT to deal with antitrust litigations is perceived to be 'the most significant and

14 http://www.catribunal.org.uk/242/About-the-Tribunal.html.

15 Full jurisdiction of the CAT includes collective actions and appeals against decisions of the Competition and Markets Authority (CMA) and by designated sector regulators see: Competition Appeal Tribunal, Annual Report and Accounts 2016/2017, p. 2-3.

16 See Ibidem, p. 5.

17 See i.a. http://www.catribunal.org.uk/242/About-the-Tribunal.html and Slaughter and May, 2017, p. 4-5.

18 Competition Appeal Tribunal, Annual Report and Accounts 2016/2017, p. 6.

19 https://www.gov.uk/government/organisations/competition-appeal-tribunal. 
positive development in the field of private antitrust enforcement in the UK since the advent of the Competition Act 1998 and the creation of the CAT' (Barling, 2013, p. 4). This became the case particularly after the reform that allowed the CAT to judge not only follow-on but also stand-alone types of claims ${ }^{20}$. The constraints which existed previously caused claimants to lack the capability to sue the violator if the action was not preceded by a decision of a competition authority confirming the infringement, as well as other procedural difficulties - these were subsequently strongly criticised (Barling, 2013, p. 5-6). As a result, the aforementioned extension of the CAT's power is welcomed by judges and other practitioners (Freeman, 2016, p. 9-10). Furthermore, another source of enthusiasm involves the CAT's ability to deal with antitrust cases involving economic and business knowledge and experience in the field of competition, due to the mixed law and economics composition of the panel. The specialization of the CAT eliminates the risk of resolving antitrust cases by judges who are not familiar with competition law and related issues (Robertson, 2017, p. 2). However, in all fairness, it should also be noted that while the judgements of the CAT include economic analyses encompassing a wide range of antitrust-related issues and anti-competitive practices, not every assessment of the CAT is fully endorsed by experts outside the CAT. These include, for example, the CAT's analysis of discriminatory terms of contracts for the supply of $\mathrm{coal}^{21}$, calculation of loss caused by the abuse of a dominant positions in relevant markets ${ }^{22}$, or incorrect application of the legal test for excessive pricing (Reger, 2018). However, the latter judgement faced criticism regarding the wrongness of the CAT's assumption about the economic value of products and - as the critics state - defective concept of 'fair prices'. As said, critics argue that reasonably behaving entrepreneurs will always seek to maximize profits, which has nothing to do with 'setting prices that bear a reasonable relation to the economic value of the product.' As a result, 'it is difficult to grasp the economic meaning of unfairness' (Reger, 2018, p. 2-3).

The conclusion mentioned above is undoubtedly interesting and worthy of further discussion in the field of competition in its various aspects, both private and public. Irrespective of this criticism the author of this paper believes that the legal and economic experience of the CAT's panel is of great importance when resolving antitrust disputes. Judges' lack of experience in economics can

20 Competition Appeal Tribunal, Annual Report and Accounts 2016/2017, p. 2.

21 See Enron Coal Services Ltd. (in liquidation) v. English Welsh \& Scottish Rail Way Ltd. (http://www.catribunal.org.uk/237-3346/1106-5-7-08-Enron-Coal-Services-Limited-inliquidation.html).

22 Albion Water Limited v. Dîr Cymru Cyfyngedig (http://www.catribunal.org.uk/2386629/1166-5-7-10-Albion-Water-Limited.html). 
cause great inefficiency when deciding private antitrust cases. It can result in poor quality of judgements too. Therefore, whereas it is hard to say that any model is ideal, certainly the UK model including specialized court dealing with antitrust litigations is worth considering 23 .

\section{Antitrust Litigation in the Netherlands and Germany}

\section{The Netherlands}

As mentioned before, apart from the UK, the Netherlands and Germany are the EU Member States with the most developed antitrust damages actions as compared to other EU Member States (Kuijpers et al., 2015). In the Netherlands, however, roughly a decade ago, when one of the reports preceding the Directive was being drafted, the number of cases in which the plaintiffs were awarded damages was limited (Van Themaat, Hettema and Buruma, 2004). Over the years, starting from the time of the aforementioned report, the situation with respect to the courts that have jurisdiction to hear antitrust damages claims has not changed.

In the first instance, a plaintiff can file their complaint to one of the civil courts - Sub-District Court or Civil Court - depending on the amount of damages sought. Appeals against judgements issued by the courts of first instance can be lodged before the Civil Court (from the Sub-District Court) or the Court of Appeal (from the Civil Court) (Van Themaat et al., 2004, p. 2). The Netherlands did not implement special jurisdiction, neither courts nor tribunals, to deal with antitrust damages claims. As a result, there are no specialised courts to hear private antitrust enforcement cases (Van Themaat et al., 2004, p. 2; Leeflang, Kuijper, 2013, p. 94). However, even without specialized courts, the Netherlands became one of the most preferred venues to file cases based on competition law violations in Europe. The significant number of antitrust litigations in Dutch courts presumably results from the relatively low costs of proceedings, as well as the expertise and pragmatic approach of the judiciary (Cornelissen, Dempsey, Knigge, Sluijter, Van Themaat, 2018, p. 206). Relevant is also the interesting development of Dutch courts regarding their jurisdiction, 'anchor defendant's rule' included (Cornelissen et al., 2018, p. 188-189; Kuijpers et al., 2015, p. 2-3). This extension of jurisdictional power can additionally increase the number of cases being brought before Dutch courts.

${ }^{23}$ See more about this debate in Poland and the arguments for the need of specialized courts in antitrust litigations Berrnatt and Gac, 2017, p. 11. 


\section{Germany}

Unlike in the vast majority of EU Member States, Germany has a long and wide spread legacy of private antitrust enforcement. Over the last decade, in particular following the $7^{\text {th }}$ Amendment of the Act Against Restraints of Competition, which came into force on 1 July 2005, German courts have gone on to register several hundred private antitrust cases every year (Buntscheck and Stichweh, 2015, p. 154; Peyer, 2010, p. 9 and p. 27). Furthermore, currently almost every cartel investigation conducted by the German competition authority is followed by antitrust damages claims (Zuehlke, 2018, pp. 109-110). Regarding competent courts, we find ordinary German civil courts dealing with antitrust litigations. This means that there are no specialized courts or tribunals resolving antitrust disputes in Germany. In the first instance, depending of the value of the case (up to or above 5000 Euro), respectively either local or regional courts deal with competition litigations. However, bearing in mind the generally significant value of antitrust cases, plaintiffs usually bring their cases to regional courts. Appeals against first instance judgements may be filed to the Higher Regional Court and then, based on points of law, to the German Federal Supreme Court (Zuehlke, 2018, p. 111; Buntscheck and Stichweh, 2015, p. 154).

In spite of the lack of formal antitrust specialization in German courts regarding competition matters, an interesting development in this respect is worth mentioning. German Federal States (Lands) are authorised to designate one regional court to deal with antitrust cases for the district of several regional courts. Since the States usually exercise this right, there is a limited number of courts specifically dealing with antitrust litigations in Germany (Buntscheck and Stichweh, 2015, p. 154). This results in a practical antitrust specialization and expertise of the pre-selected courts, instead of a formal one. Furthermore, the courts tend to assign antitrust cases to one or a limited number of panels. As a consequence, all panels dealing with competition law cases are practically specialized in the field of private antitrust enforcement. Therefore, many courts dealing with antitrust cases possess wide knowledge and experience in antitrust litigations (Wach, Epping, Zinsmeister and Bonacker, 2004, p. 3).

Subsequently, despite the lack of a formal status, the specialization of German courts in antitrust litigations based on experience should not be questioned. It is worth noting, however, that this type of specialization based on experience - called 'repeat exposure' to antitrust litigations - is debatable ${ }^{24}$.

${ }^{24}$ See remarks regarding the ability of generalist judges to cope with sophisticated economic issues in private antitrust cases even though they have economic training and 'exposure' to antitrust litigations Baye and Wright, 2010. 
The aforementioned experience is reflected in a significant number of antitrust litigations being dealt with by German courts. This number cannot easily be matched by other EU Members States. As a consequence, due to experience in antitrust law, plaintiff-friendly rules, a comparatively short duration of the proceedings and their moderate costs (Buntscheck and Stichweh, 2015, p. 154), as well as wide reach of availability in terms of extraterritoriality rules (Zuehlke, 2018, p. 112), German courts have become one of the jurisdictions of choice for many claimants in antitrust cases from other EU Member States (Zuehlke, 2018, p. 109-110). Even considering differences within legal frameworks, the similarity between Germany and the UK is noticeable.

\section{Court Models in other European Union Countries}

Courts competent in private antitrust cases in other EU Member States are discussed in the following sub-sections. These are the States where private enforcement is not as developed as in the examples discussed above. Nevertheless, the situation in many of them is changing significantly, in particular upon the implementation of the Directive. Unlike the previous section, this one is split into several sub-sections due to the number of Member States being discussed herein. The division is based on the criteria of specialized, quasi-specialized and ordinary courts.

\section{Specialized and quasi-specialized courts}

\subsection{Portugal}

In Portugal the number of private antitrust enforcement cases is not significant, however, some indicators of an upcoming change, in particular a few private antitrust cases, are noticeable (Anastácio and Anastácio, 2018, p. 237). Before the implementation of the Directive, recently transposed by means of Law 23/2018, 5 June, ordinary civil courts were empowered to judge private antitrust cases (Anastácio and Anastácio, 2018, p. 238). The new law changes this system and grants exclusive jurisdiction in the first instance to the Competition, Regulation and Supervisory Court that is to decide in actions for damages based on violations of competition law ${ }^{25}$. Appeals regarding decisions made by this court can be filed to the Appellate Court. The latter

${ }^{25}$ See i.a. at the time of the draft of the new law: De Sousa e Alvim, 2017, p. 215; Anastácio and Anastácio, 2018, p. 239 and 248. 
court's decisions can, in turn, be reviewed by the Supreme Court (Anastácio and Anastácio, 2018, p. 239). However, even considering the fact that Portugal decided to set up specialized jurisdiction to review antitrust damages cases, and the significant role of the Portuguese Competition Authority in promoting private antitrust enforcement, bearing in mind the uncertainty around litigation costs and the financial crisis, it is unlikely that the number of antitrust cases will significantly grow in the near future (Anastácio and Anastácio, 2018, p. 249).

\subsection{Spain}

The Spanish model of jurisdiction in antitrust damages claims has recently evolved as well. Until 2007, allowed were only private actions based on domestic competition law preceded by final and definitive decisions issued by the Spanish Competition Defence Tribunal. Thus, only follow-on actions were available to plaintiffs seeking compensation to recover damage caused by a violation of competition law. This rule, finally repealed in 2007, resulted in significant obstacles and delays in pursuing private antitrust litigations (Marcos, 2013, p. 2-3). The existence of a factual delay was confirmed in one of the studies, which identified 323 cases in Spain in the period between 1999 and $2012.94 \%$ of them constitutes stand-alone cases, while only 18 cases are follow-on (Marcos, 2013, p. 8). Interestingly, only one case out of the 323 was brought by consumers (De Ávila Ruiz-Peinado, 2016, p. 1). Commercial courts were created in 2004 to deal with private antitrust cases based on Articles 101 and 102 TFEU, that is four years before the aforementioned rule was finally dropped making it possible for plaintiffs to bring stand-alone actions. Eventually, those courts are to deal with antitrust litigations both kinds of domestic cases as well as those based on EU competition law (De Ávila Ruiz-Peinado, 2016, p. 5). Another interesting observation regarding courts making decisions in antitrust damages cases indicates that $66.25 \%$ of the cases have been decided by the Provincial Court of Appeals while only $24.5 \%$ went to the Supreme Court (De Ávila Ruiz-Peinado, 2016, p. 10) ${ }^{26}$. Recently, development of private antitrust enforcement has not changed significantly, however there are several important cases being reviewed by Spanish courts at the moment (Gutiérrez and Arranz, 2018, p. 277-278).

The law implementing the Damages Directive, namely the Royal Decreelaw 9/2017, of 26 May (RDL 9/2017) (Gutiérrez and Arranz, 2018, p. 279), did not change existing rules regarding jurisdiction in antitrust cases. The rules are, however, not uniform and can cause some doubts in their practical application. While according to the general principle, commercial courts hear

${ }^{26}$ The gap results from pending proceedings that were not yet resolved when the study was drafted. 
antitrust damages claims, both stand-alone and follow-on cases (De Ávila Ruiz-Peinado, 2016, p. 13; Gutiérrez and Arranz, 2018, p. 280), there are some antitrust-related cases that are reviewed by ordinary civil courts. The latter takes place when a defendant invokes competition rules to challenge a plaintiff's complaint. In these cases, ordinary civil courts have jurisdiction, instead of commercial courts (Gutiérrez and Arranz, 2018, p. 280).

It is also worth noting that commercial courts are meant to be specialized courts to deal with antitrust cases (De Ávila Ruiz-Peinado, 2016, p. 13; Gutiérrez and Arranz, 2018, p. 280), which can cause some doubts in the juxtaposition with courts which, in some Member States, are exclusively specialized in antitrust matters. The most characteristic example of this is the CAT in the UK. Moreover, Spanish judicial rules make it possible to file follow-on actions in ordinary civil courts, provided that they are limited to seeking damages and therefore do not differ from any other civil damages claim (Gutiérrez and Arranz, 2018, p. 280). This can only cause another question regarding the actual specialization of Spanish courts in antitrust-related cases. Appeals from decisions of the courts of first instance can be lodged before the Provincial Courts and, finally, to the Supreme Court following a standard civil procedure.

Analysing the Spanish model of jurisdiction in antitrust-related cases, it is worth noting that in some cases courts used economic analysis in order to quantify damages ('economic estimation of damages') or, when necessary, even for other purposes in the proceedings (De Avila Ruiz-Peinado, 2016, p. 39; see also Delgado and Perez-Asenjo, 2011). Therefore, as the authors of one of the studies pointed out, the courts handle the cases quite well, with adequacy and pragmatism. This, in turn, made it possible to detect, and in some cases to reject, actions that were brought only strategically, with no substantial merit (De Ávila Ruiz-Peinado, 2016, p. 32-33) ${ }^{27}$. This shows good prospects for future developments of private antitrust enforcement in Spain (Gutiérrez and Arranz, 2018, p. 289).

\subsection{Italy}

In Italy, upon the publishing of the Green Paper ${ }^{28}$, a very interesting discussion emerged about those empowered to pursue private antitrust litigations. This issue is closely related to the type of courts available to plaintiffs to bring their private antitrust actions. The primary question was, if the right to file a complaint is available only to undertakings, directly addressed by

\footnotetext{
27 See about strategic abuse of antitrust law in litigations McAfee and Vakkur, 2004.

28 Green Paper Damages actions for breach of the EC antitrust rules Brussels, 19.12.2005, $\operatorname{COM}(2005) 672$ final (accesible at: https://eur-lex.europa.eu/legal-content/EN/TXT/ $\mathrm{PDF} /$ ?uri $=$ CELEX:52005DC0672 \&from $=\mathrm{EN})$.
} 
competition law, or also to consumers, that can benefit from private antitrust enforcement. There were several different - in some cases even contradictory - judgements on this subject, judgements of the Italian Supreme Court included, swinging between giving and not giving this possibility to consumers. The opinion of the Italian doctrine referring to the Courage v. Crehan ${ }^{29}$ case was also divided. It had some significance in relation to the court competent in antitrust-based litigations too (Castronovo, 2007, p. 107-112).

From that time, Italy has come a long way and the discussion outlined above has lost its significance. As early as 2015, before the implementation of the Directive, the Italian Supreme court set up some guidelines in the Cargest case for Italian judges dealing with private antitrust cases. According to these guidelines, judges should use in antitrust proceedings tools provided for by the Italian Civil Procedure Code, such as expert witnesses and requests for documentation and information addressed to private and public entities (Raffaelli, 2018, p. 165). The current model of courts competent in private antitrust actions was established by the Italian Legislative Decree No. 3/2017,30 which came into force on 3 February 2017 implementing the Directive. Unlike the previous model, in which all business courts across Italy had such jurisdiction, according to the new law the three Companies Tribunals located in Rome, Milan and Naples are specialized courts having exclusive jurisdiction in antitrust cases of both kinds, stand-alone and follow-on (Toffoletti and De Stefano, 2018, p. 7; Raffaelli, 2018; p. 167). The judgements of the tribunals can be challenged before the Court of Appeal. The appellate court has the power to fully review the merits of the case. Then, the judgement of the Court of Appeal can be challenged before the Supreme Court but only on points of law (Toffoletti and De Stefano, 2018, p. 25).

The specialization of the tribunals competent in antitrust cases is welcomed as antirust actions need specialized judges to review all their aspects covering not just the law but also their economic, business, market aspects, etc. Furthermore, due to this specialization, the duration of the proceedings in antitrust cases is expected to be shorter (see also: Raffaelli, 2018, p. 167; Toffoletti and De Stefano, 2018, p. 12).

\subsection{France}

The number of private antitrust cases in France is relatively low (Oster, 2018, p. 100). This can be surprising considering the scale of the French economy and market. The development of the French model of courts competent in antitrust litigations is very interesting too. Even considering that

29 See: https://eur-lex.europa.eu/legal-content/EN/TXT/?uri=CELEX\%3A61999CJ0453.

30 The Official Journal of the Italian Republic, General Series No. 15, of 19 January 2017. 
the French Competition Council (hereinafter; FCC) has the mandate to only deal with cases that represent the general interest at least in some part, it was quite common for a plaintiff representing private interests to file a complaint directly to the FCC. This way the FCC was becoming a specialized court in private antitrust enforcement cases, due to the fact that more than half of them were brought by firms, competitors and other victims. Therefore, there was a need to debate and to review that hybrid status of the FCC, which has been caring out a specific type of private enforcement (Idot, 2007, p. 90-91).

Another part of French developments constitutes the discussion of courts competent in private antitrust cases. It is mainly related to civil courts, which include those dealing with commercial matters, however, some issues concern administrative courts as well (Idot, 2007, p. 91-92). As a consequence, another discussion took place, this time pertaining to the need for specialization of courts in competition-related cases, as it happened previously in the case of intellectual property claims. Eventually, several courts were selected in order to deal with private antitrust enforcement cases, however, neither the number nor the geographical location was satisfactory enough. The latter was particularly important since the selected courts were not located in the most important economic areas. The same disappointment concerned the number of appeal courts. It was expected that at least eight were going to be chosen, whereas ultimately only one, the Court of Appeal of Paris, was appointed (Idot, 2007, p. 92). The aforementioned discussions and the following changes in the French court system, relating to its ability to efficiently resolve private antitrust cases, resulted in a significant improvement of the system. There are also examples of cooperation between the French competition authority and courts where advice was being given by the FCC to the courts regarding, among others, the definition of the relevant market (Idot, 2007, p. 92-93).

Currently in France, upon the adoption of Ordinance 2017-303 and Decree 2017-305 of 9 March 2017 that implemented the Directive, antitrust-based private actions can be brought before commercial or civil courts. Within these entities, courts specialised in hearing competition damages claims have been appointed. The actions are headed to the commercial court if the dispute is between companies or commercial entities. If this is not the case, civil courts have jurisdiction to hear the claim ${ }^{31}$. The aforementioned rule is, however, not uniform due to the engagement of administrative courts. Where a public entity is involved, as a violator or a victim, an action can also be brought before administrative courts (Oster, 2018, p. 100-102). If the party is not satisfied by the judgement, then it can lodge an appeal based on a point of fact or law before the Court of Appeal. In private antitrust cases, the only

31 Competition Litigation in France (https://globalcompliancenews.com/antitrust-andcompetition/competition-litigation-in-france/). 
competent court to review these judgements is the Paris Court of Appeal, if the judgment is delivered by a lower court specialized in competition law matters. If the party is to challenge the judgement of the Court of Appeal, then, only based on a point of law, it may lodge a further appeal to the Supreme Court. Judgements delivered by administrative courts can be challenged before the Administrative Court of Appeal and then to the Council of State ${ }^{32}$.

\subsection{Bulgaria}

In Bulgaria there were some controversies pertaining to the value and nature of antitrust damages claims, which led to a dual approach to courts competent in antitrust litigations. Usually cases with the value of the claim below approximately 12500 Euro are to be reviewed by district courts (single judge, ordinary procedure); cases with a higher value of the claim are heard by a provincial court (panel of three judges). However, if a private antitrust case was qualified as commercial disute - based on its value and nature - then it would be directed to a provincial court under the procedure for commercial disputes. Irrespectively of the aforementioned aspect of competence between district and provincial courts, there is no specialized court in Bulgaria to deal with private antitrust enforcement claims. As a consequence, Bulgarian jurisdiction can be qualified as a quasi-specialized as well as a non-specialized one. Interestingly, Bulgarian courts refused to proceed with stand-alone private antitrust cases and only accepted private claims for cases that follow decisions of the Bulgarian competition authority (Petrov, 2017, p. 33-34).

\subsection{Croatia}

Croatia, like Bulgaria, implemented the rule under which private enforcement cases are being directed to commercial courts. These are specialised courts having experience in commercial disputes, a fact that should help them resolve complex competition-related issues. Nevertheless, the idea of antitrust specialisation within commercial courts was abandoned after limited consideration (Butorac Malnar, 2017, p. 61-62).

\subsection{Latvia}

Latvia set up a quasi-specialized court, namely the Riga city Latgale district court, in order to resolve private antitrust disputes. The intention is to ensure that antitrust claims are being reviewed by experienced and knowledgeable

32 Competition Litigation in France... 
judges. There is, however, one problem with this approach. While the judges in the Riga city Latgale court - after specific training and some experience in dealing with competition litigations - will be ready to deal with antitrust claims with experience and knowledge, their judgements can only be challenged before the Riga Reginal court of appeal. The latter is, in turn, an ordinary civil court not specialized in competition litigations. There is also the possibility to file for cassation to the Supreme Court (Jerneva and Druviete, 2017, p. 160).

\subsection{Lithuania}

Lithuania established the Vilnius Regional Court as the exclusive first instance court to hear private antitrust cases as early as 2004, the time when Lithuania joined the EU. This means that this court already has some experience in reviewing competition-based private cases. However, its exclusive power is not fully recognized by other courts and, as a result, some cases can be directed to other courts, mainly administrative ones. The latter situation can particularly happen when at least one State-owned entity is involved in the trial. This means, in turn, that despite the aforementioned specialization, there is still some theoretical and practical vagueness relating to jurisdiction in antitrust litigations. Appeal from the first instance judgement can be heard by the Court of Appeal of Lithuania and, afterwards, under the cassation procedure, an extraordinary appeal can be submitted to the Supreme Court of Lithuania. Nevertheless, if the case was adjudicated in the first instance by an administrative court, then the appeal can be lodged to the Supreme Administrative Court as the final forum to review the case (Mikelenas and Zaščiurinskaitè, 2018, p. 184-188). As a result, despite Lithuanian lawmakers' intention to appoint specialized jurisdiction in competition-based private claims, there is still tension and ambiguity relating to the forum in such cases.

\subsection{Romania}

Unlike the aforementioned examples of special jurisdiction, there were originally no specialised courts to decide on antitrust litigations in Romania. Therefore, not surprisingly, the lack of experience of judges of lower courts in the field of competition law was emphasised (Mircea, 2017, p. 238). This situation has recently changed. According to the new rules implementing the Directive - the Government Emergency Ordinance No. 39/2017433 - the exclusive jurisdiction over the award of damages to individuals in cases of violations of Articles 5 and 6 of the Competition Act and Articles 101 and 102

33 Government Emergency Ordinance No. 39/2017, the Official Journal of Romania, Part 1, No. 422 of 8 June 2017. 
TFEU belongs to the Bucharest Tribunal and, consequently, to the Bucharest Court of Appeal (Ion, Ambrozie and Nistor, 2018, p. 252).

\subsection{Slovakia}

In Slovakia there are quasi-specialized courts in matters relating to the economy and competition that are the subject of litigation. These courts are the District Court in Bratislava II in first instance, and the Regional Court in Bratislava to review the appeals from the first instance judgements. The second instance judgements can be challenged before the Supreme Court. The aforementioned specialization is though questioned for several reasons, mainly the fact that all courts should resolve all types of cases (civil, commercial, family, etc.), as well as the fact that many matters relating to business, commerce and unfair competition are being dealt with by other courts too. This means, in turn, that the specialization of the court assigned to antitrust litigations is dubious (Blažo, 2017, p. 250-251).

\subsection{Slovenia}

Slovenia does not have specialized courts dealing with antitrust damages claims. Nevertheless, antitrust litigations are qualified as commercial due to its competition protection nature. This means that these cases may be brought before the district courts in the first instance, instead of local courts that generally have the competence to adjudicate civil cases in the first instance. Usually, a single judge reviews the commercial case unless a panel of three judges is appointed due to the complexity of the case. An appeal from the first instance judgment can be lodged to the high courts (panel of three judges), and then, under specific conditions (only questions of substantive law and serious breaches of procedure), the case can be reviewed by the Supreme Court (Vlahek and Podobnik, 2018, p. 272-274). Nevertheless, the aforementioned commercial specialization does not mean that there is a particular specialization for competition damages claims. Thus Slovenia does not have courts that have particular specialization in reviewing competition law issues in civil proceedings.

\section{Ordinary jurisdiction}

\subsection{Austria}

In Austria, as in other European States, the number of competition law-based litigations is constantly growing after the implementation of the Directive. There is no specialized court to adjudicate private antitrust 
litigations. The amendment to the Austrian Cartel Act, introducing new rules governing private antitrust damages claims, does not change the rule according to which ordinary civil courts resolve antitrust disputes (Elsner, Zandler and Kos, 2018, p. 42). As a result, it is worth noting that Austria, even though it implemented the Directive, is not perceived as an attractive forum for antitrust litigations (Elsner et al., 2018, p. 50).

\subsection{Czech Republic}

The Czech Republic did not establish any courts specialized exclusively in competition matters to hear antitrust litigations. Therefore, according to its civil procedure rules, regional courts with a single judge deal with competitionbased cases in the first instance. These courts have the jurisdiction to deal with more complex cases also, antitrust litigations included. An appeal from a regional court can be lodged to a superior court with a panel of three judges. There are eight regional and two superior courts in the Czech Republic. The judgement of a superior court can be challenged, by way of an extraordinary appeal, before the Supreme Court under specific circumstances (Petr, 2017, p. 89).

\subsection{Estonia}

Specialized courts to deal with antitrust damages claims were not appointed in Estonia. Therefore, competition law-based litigations are being reviewed by civil courts.

\subsection{Hungary}

In Hungary, like in Estonia, specialized courts were not appointed either. Irrespective of the value of the case, regional courts have exclusive competence to deal with antitrust litigations. An appeal against their judgements can be lodged to a regional court of appeal. Furthermore, the Hungarian Supreme Court reviews extraordinary appeals if filed by one or both of the parties (Pärn-Lee, 2017, p. 111; Miskolczi Bodnár, 2017, p. 137).

\subsection{Poland}

When implementing the Directive, Polish lawmakers did not decide to appoint special jurisdiction to resolve antitrust disputes. However, unlike in the ordinary civil procedure, regional courts have exclusive jurisdiction in this type of litigations in the first instance (whereas according to ordinary 
procedure, district courts are to deal with civil cases in the first instance). The idea behind this exception is to direct competition-based litigations to regional courts as these have more expertise and are more experienced to handle complex cases. Judgements of the regional courts can be challenged before the appeal courts and then, under specific circumstances, an extraordinary appeal can be lodged to the Supreme Court. Thus there are no specialized courts to deal with antitrust litigations in Poland, even if the idea of specialized courts or chambers having competition law and economic knowledge has been considered (Piszcz and Wolski, 2017, p. 215) 34. $^{34}$

\section{How Binding Effect and Judicial Review of NCAs Decisions Can Affect Adjudicating in Antitrust Litigations?}

The aforementioned two elements very often accompany discussions regarding private antitrust enforcement. This is because these factors seem to affect the way the courts decide in antitrust litigations, or at least, can have some influence on the judicial decisions. Sometimes the same courts adjudicate antitrust litigations and review NCAs decisions. In relation to the binding effect of NCAs decisions, it is worth noting that, first, the judicial approach has been changing over the years and, second, how this approach differs between Member States. The change that happened between the preDirective era and afterwards is radical, however, some important questions are still waiting to be resolved. Regarding judicial review of NCAs decisions, the tendency to refer to EU and national courts in the context of private antitrust enforcement seems to be natural. This pertains particularly to the scope of judicial scrutiny when reviewing NCAs decisions in relation to fact findings, their assessment, as well as the legal grounds of a decision in question in both stand-alone and follow-on types of cases. Bearing this in mind, the author's intention is not to discuss the binding effect and judicial review of NCAs decisions in all the States being mentioned above. Instead, this section of the article aims to discuss the development and the state of play of the aforementioned elements based on selected examples and the main rules of a given legal system.

To begin with, in the American model of private antitrust enforcement, there is no rule establishing the binding effect of prior administrative agency decisions, namely the Federal Trade Commission. This, however, does not mean that the court in antitrust litigation cannot recognize the findings or

\footnotetext{
${ }^{34}$ See also critical remarks regarding the lack of special jurisdiction Bernatt and Gac, 2017, p. 11.
} 
a prior FTC decision, but the determination if those findings, or any part of a decision, have probative value in private litigation is left to the discretion of the court ${ }^{35}$. For such determination, the key is to satisfy the requirements of collateral estoppel (primary that the issue was identical, there was full and fair opportunity for the party to litigate, the factual finding was essential for the decision, the judgement was valid and final) ${ }^{36}$. In case of civil lawsuits following criminal investigations, there is a possibility for a claimant to rely on the DOJ's investigations and convictions ${ }^{37}$. Furthermore, section 5(a) of the Clayton Act sets forth rules on prima facie evidence in relation to the final judgement or decree rendered in any civil or criminal proceedings brought by the United States. Regarding foreign tribunals' decisions, they may have preclusive effect in US proceedings provided that the judgement or its findings meet requirements of impartiality and due process ${ }^{38}$. The latter rule had practical relevance in proceedings before the US District Court for the District of Columbia where the court considered the EC's findings in the antitrust litigation involving bulk vitamins ${ }^{39}$ (Saint-Antoine, Lewers, Hutchison, Bullard and Michelen, 2016).

With respect to judicial review of FTC decisions ${ }^{40}$, the party that is addressed as violating antitrust law can lodge an appeal against a FTC decision to the U.S. Circuit Court of Appeals. The appellate court reviews both legal and factual grounds of the decision in question. There is, however, the assumption in the American model of antitrust enforcement that the agency has superior competences in questions of fact, whereas the reviewing court has superior competence in issues of law (see Laguna de Paz, 2012, p. 8; Merril, 2010, p. 389). The courts use the standard of 'substantial evidence test'. In the aftermath of a judicial review of a FTC decision, the court can affirm it, modify it or set it aside. Then, if the party dissatisfied with the court's decision is granted a Petition for Certiorari, it can bring the case before the U.S. Supreme Court. Otherwise, the Appellate Court's judgement becomes final ${ }^{41}$. In the UK, before the transposition of the Damages Directive, the claimant could rely upon the findings of a competition authority (both the UK Competition and Market Authority (hereinafter; CMA) and the EC) as

35 See BoDeans Cone Co v. Norse Dairy Sys. LLC, 678 F. Supp. 2d 883, 897 (ND Iowa 2009).

36 See also United States v. Utah Const \& Min Co, 384, 422 (1966).

37 See Hinds Ctv, Miss v. Wachovia Bank NA, 700 F. Supp. $2 d$ 378, 394-95 (SDNY 2010).

38 See United States v. Kashamu, 656 F. $3 d$ 679, 683 (7th Cir 2011).

39 See In re Vitamins Antitrust Litig, 320 F. Supp. $2 d 1$ (DDC 2004).

${ }^{40}$ FTC issues cease and desist orders in two instances - first is Administrative Law Judge and then, the findings are being controlled by the panel (FTC Full Board).

${ }^{41}$ For more about 'substantial evidence test' and its application by the U.S. courts see Bernatt, 2017. 
proof of a breach ${ }^{42}$. Starting from 1 October 2015, both the HC and the CAT are bound by final decisions of the CMA and the EC. In relation to decisions of NCAs of other EU Member States, following the Directive, these decisions constitute prima facie evidence of a breach of competition law before the UK courts (see more Adkins and Beighton 2016, p. 26-27 and Nazzini, 2015, p. 80-91). Decisions taken by the CMA based on the Competition Act 1998 and Articles of 101 and 102 TFUE are being reviewed by the CAT ${ }^{43}$. As discussed in this article, this is also the court of jurisdiction competent in private antitrust litigations.

Before the transposition of the Directive, the approach of the French judiciary to the issue of a possible influence of findings taken in a prior decision of a NCA was based on the civil concept of fault within the meaning of tort law. As derives from case law, the courts differ in their decisions depending whether the authority that issued the decision was the EC or the French Competition Authority (hereinafter; FCA). In the first example, the courts recognized that a breach of competition law confirmed in an EC decision is deemed as fault in antitrust litigations (due to Article 16 of Regulation $1 / 2003^{44}$ ). By contrast, if the findings came from a FCA decision, this was not consider as fault.

Over the years this situation has been changing and findings of the FCA were increasingly recognized as having probative value in private antitrust cases. Even in stand-alone cases, however, the French Commercial Code gives the right to the plaintiff to ask the court to request the FCA, as amicus curiae, for its opinion with respect to competition-related aspects of a litigation (for example, if an undertaking has a dominant position). Therefore, even not having binding effect as stated in section 9(1) of the Damages Directive, findings of an infringement of competition law could assist the plaintiff considerably in proving fault in antitrust litigations (Lenoir, Plankenstainer and Truffier, 2015, p. 128-129; Thill-Tayara and Asins, p. 169 and 178). Upon the transposition of the Damages Directive, the infringement of competition law established in a decision of the FCA and EC (or court of appeal) that cannot be further challenged has binding effect in private antitrust litigations (the infringement is deemed as irrefutably established). With respect to decisions of competition authorities from other EU Member States, their findings are deemed to constitute prima facie evidence (Oster, 2018, p. 105).

In relation to the judicial review of FCA decisions in the French model, they are subject to the jurisdiction of civil court (the Court of Appeal), except

\footnotetext{
42 See Department for Business Innovation \& Skills (2016).

43 See Competition Appeal Tribunal, Annual Report and Accounts 2016/2017, p. 2.

44 Council Regulation (EC) No. 1/2003 of 16 December 2002 on the implementation of the rules on competition laid down in Articles 81 and 82 of the Treaty (OJ L 1, 4.1.2003, p. 1-25).
} 
merger control decisions that are being reviewed by the Council of State (administrative jurisdiction). When reviewing administrative decisions, the civil court examines facts and law and, as a result, can declare a FCA decision void. If it does so, then the court has to replace or modify the decision in question. (Laguna de Paz, 2012, p. 8-9). The Paris Court of Appeals has exclusive jurisdiction to challenge FCA decisions. This model derives from the assumption that experienced courts that usually hear cases from the area of commercial, civil and criminal law are already well-suited for reviewing FCA decisions (Petit, 2009, p. 107-110). Considering the French civil courts-based model, it is worth noting that the Court of Justice's landmark decision in the Tetra Laval case ${ }^{45}$ did not change the courts' standard of judicial review in France. Despite the Court of Justice's recommended 'selected' review, whereby courts' scrutiny should target only a limited set of features of EC decisions, French courts maintain their standard of judicial review. As a result, French courts, based on well-established principle of procedural autonomy, apply a more stringent standard of review of FCA decisions than this set out by the Court of Justice in the Tetra Laval BV case (see more Petit, 2009, p. 105-124).

Like in France, in Italy before the transposition of the Directive by the Legislative Decree No 3/2017, facts established in a decision of the Italian Competition Authority's (hereinafter; ICA), even though considered as privileged evidence, were not binding in private enforcement cases. The court had to assess the merits of the case autonomously from any assessments made by the administrative authority. This was because of the distinction between the role of the courts (resolving conflicts between persons) and the competition authority (controlling the market in the public interest). In practice, the findings of the ICA are relied upon by Italian courts, in particular its economic assessments. Consequently, due to the evidential value of the findings, it was very difficult to rebut the findings of the ICA for the parties, even though in principle those findings were not binding for the judge (Tardella and Maggiore, 2004, p. 24-25). Upon the transposition of the Directive, a final decision of the ICA has binding effect in civil proceedings (Toffoletti and De Stefano, 2018 , p. 2). Differently to most of the above mentioned examples, in Italy decisions of the ICA are being reviewed by administrative courts (Consiglio di Stato). This administrative body controls both the law and facts (Laguna de Paz, 2012, p. 9).

In the past, final Statements of the German Competition Authority (hereinafter; GCA) had to be accepted by civil courts, but the courts usually did not consider themselves bound by legal and fact findings established in

${ }^{45}$ Case C-12/03 P Commission v. Tetra Laval BV [2005], ECR I-987. 
GCA decisions. Still, the courts were aware that they should not rule against decisions of the EC stating that certain conduct constitutes a violation of EU competition law (see Wach et al., 2004, p. 17). In the wake of the $7^{\text {th }}$ amendment to the German Act Against Restrains of Competition (AARC) that came into force 1 July 2005, civil courts are bound by the decisions of the GCA, the EC and the NCA of another Member State on the infringement of competition law (see Wach et al., 2004, p. 17; Peyer 2010, p. 12). In relation to judicial review, the parties can appeal a GCA decisions to the Düsseldorf Higher Regional Court. Judgement of this court can be further challenged before the Federal General Court of Justice in Karlsruhe (The Bundeskartellamt in Bonn, p. 36).

In Poland, the prejudicial nature of administrative decisions, decisions of the Polish Office of Competition and Consumer Protection (hereinafter; OCCP) included, was not regulated by law but derived from jurisprudence. However, the prejudicial character of OCCP decisions was rather common in Polish legal doctrine, provided that the decision is final and cannot be further challenged (Jurkowska, 2010, p. 74). The need for comprehensive findings in OCCP decisions and the courts' rulings in competition-related cases has been confirmed by the Polish Supreme Court too (Jurkowska-Gomułka, 2013, p. 289). This rule was eventually established as a result of the transposition of the Directive into the Polish legal system. With respect to the decisions of NCAs from other Member States, Polish lawmakers considered that there is no need to adopt a specific regulation due to currently existing rules in the Polish Code of Civil Proceedings (hereinafter; PCCP). This is, however, controversial considering the different nature of 'prima facie evidence' as stated in section 9.1 of the Directive, and 'factual evidence' according to Article 231 PCCP (see Bernatt and Gac, 2017, p. 9-10). Decisions of the OCCP are being reviewed by the Court of Competition and Consumer Protection. This is a civil court and its review is based on a de novo character, which means that the court examines all aspects of the decision, that is, law and facts (Bernatt, 2016, p. 101). The judgements of this court can be challenged before the Courts of Appeal and then, only based on points of law, before the Supreme Court.

This section of the paper is basically aiming at considering if the binding effect and the way of judicial review of NCAs decisions adopted by the courts can significantly affect their decision making process when handing down judgements in private antitrust enforcement cases. To begin with, the binding effect of NCAs decisions can theoretically limit the court's engagement in the analysis of 'pure' competition matters, such as the relevant market, a practice that allegedly can fail to comply with competition law, and the nature of the infringement in question itself. Relief for the court in cases where the court is only to establish the damage and causation between the infringement and 
the damage is clearly stated in the reasonings. This is because the relation between a given practice (allegedly anticompetitive) and competition law, the facts and the scope of the infringement included, is to be established by the NCA in its decision ${ }^{46}$. In particular from the perspective of section 9.1 of the Directive, the role of the court in this respect is simply to follow the relevant NCAs decision. Nevertheless, this is the case only in follow-on law suits.

Conversely, in stand-alone cases (not preceded by a NCAs decision), the court must carry out the aforementioned analysis on its own, in order to establish if all conditions of civil liability meet, or not the level required to hand down a judgement in favour of the plaintiff. Even though follow-on cases are dominating private antitrust enforcement, these are not the only cases being brought by plaintiffs. As a consequence, even considering that stand-alone cases are less frequent, a fact that has not been proven ${ }^{47}$, every court dealing with private antitrust enforcement cannot avoid scrutinising competitionrelated issues in its practice. Obviously, courts doing their job can or even should rely upon previous NCAs' decisions and analysis included therein. This, however, does not release any court from establishing the relevant market, type of infringement and its scope, as well as other conditions of liability in stand-alone private antitrust cases. This means, in turn, that while binding effect can be considered as the 'smart tool', meant to support the victims of anticompetitive conduct in antitrust litigations, it does not make a significant difference to the ability of courts to deal with complex competition cases. The courts should also continue the use of expert opinions if necessary, in order to assess their results in relation to a particular case. Extensive knowledge, experience and practice of judges when adjudicating private antitrust cases is constantly needed, irrespective of the binding effect of NCAs decisions and its role in follow-on cases.

The second issue that has been discussed in this section, namely judicial review of NCAs decisions, is directly framed within the discussion that pertains to the model of court in private antitrust cases. Based on the judgements that have been mentioned above, as well as the practice of judicial review in the EU and the US, two scopes of court intervention when reviewing competitionrelated matters of NCAs decisions have to be distinguished. The first one, which can be called 'restrained', is limiting the scope of judicial analysis when it comes to the nature of the infringement of competition law, the market and

46 See e.g. Enron Coal Services Ltd. (in liquidation) v. English Welsh \& Scottish Rail Way Ltd., Case No. C3/2010/0404 at [8] and [50] and Deutsche Bahn AG \& ORS v. Morgan Crucible Company PLC \& ORS, Case No. C3/2011/1995 at [37] (retrieved https://www.catribunal.org.uk/ sites/default/files/1173_Deutsche_Bahn_Court_of_Appeal_Judgment_310712.pdf).

47 By contrast, in Germany in the period between 2005 to 2007 stand-alone cases were dominating (see Peyer, 2010, p. 35-39). 
the economy. It focuses primarily, albeit not exclusively, on other conditions of civil liability, namely damage, its quantum and causation. This approach following the Tetra Laval BV case in the EU, is being discussed in American legal doctrine in relation to judicial deference and the 'substantial evidence test' in judicial review undertaken by the U.S. Circuit Courts of Appeal (Bernatt, 2017).

The second approach is more open for analysis of all aspects of antitrust damages claims in general, in particular competition and civil law-related matters and the nature of the competition law infringement ${ }^{48}$. As a result, it does not seem to be a too far reaching conclusion that the courts, in so far as they are more open for competition, market and economy, have greater knowledge and experience when dealing with complex antitrust litigations, stand-alone in particular. Additionally, even the Court of Justice and the courts of the Member States, not to say the Polish Supreme Court, are not fully comprehensive in their guidelines pertaining to the role of courts in judicial review of NCAs decisions, fact findings, competition law infringements, market and economic matters, as well as other aspects of competition law violation ${ }^{49}$.

In order to present an even more complicated picture of the issue, it is worth noting that, as one of the studies of judicial review of EC decisions finds, what really matters in judicial review is the origin of judges and their legal education. While judges with a common law background are more flexible in their analysis and adjudicate more in favour of the undertakings, judges with continental legal background, mainly French, are stricter. Thus, they decide more often in favour of EC decisions being questioned before the Court of Justice (Zhang, Liu, Garoupa, 2017, p. 25-26). Having said that, very often the quality of judgements rendered by judges deemed to be experts in competition-related matters is not satisfactory enough (see Polish example Bernatt, 2016, p. 106).

One of the disappointments that comes from this brief analysis derives from the fact that, if we look into it even considering such landmark decisions as Tetra Laval $B V^{50}$, it turns out that there is still a lack of a unified, comprehensive approach to this issue. The ways adopted by courts in EU Member States differ, and no agreement has been reached at this point. Paradoxically, judicial review of NCAs decisions, even if it does not constitute any part of private antitrust enforcement, seems to be more important for the quality of judgements than the binding effect of NCAs decisions in antitrust litigations. Considering different goals of public and private enforcement in general, the most important aspects of both types of cases are common. These are mostly

\footnotetext{
48 See discussion in Petit, 2009 based on French example.

49 See e.g. discussion in Bernatt, 2016 and Laguna de Paz, 2012.

50 See also Petit, 2009.
} 
findings regarding the infringement of competition law and the quantum of damage caused by the infringement. For this reason, the experience of the courts in reviewing NCAs decisions should play an important role in antitrust damages claims too. This is also the reason why some authors claim that Polish lawmakers made the wrong decision regarding the model of court in antitrust litigations, when they chose ordinary civil courts rather than the Court of Competition and Consumer Protection (Bernatt and Gac, 2017, p. 11). The latter court reviews the decisions of the OCCP and, for at least a decade, acquired knowledge and experience in the field of competition and consumer protection. As a consequence, it seems to be a well-suited venue to adjudicate private antitrust cases. As stated above, however, even this court is not always doing its job properly when analysing competition-related matters. Moreover, like the Polish lawmakers, the legislators in several other EU Member States decided to use a model of court where the judicial review of NCAs decisions and deciding on private antitrust claims is split between different types of courts. The ability of generalist judges to deal with complex competition cases is limited, as the authors of one of the studies found (Baye and Wright, 2010).

As a consequence, considering all the aforementioned aspects of the binding effect and judicial review of NCAs decisions, drawing any clear conclusions regarding the relation between these aspects and the ability of courts to deal with antitrust litigations seems to be very difficult. One is, however, relatively certain, a great part of the task and its fulfilment by the courts depends on the skills and the ability of individual judges. The more open-minded the judge, the more flexibility and readiness there is to overcome the barriers of a traditional way of judging, the more efficient private antitrust enforcement is, irrespective of the type of court chosen.

\section{Is Any Model of Court Really Ideal?}

The chart below contains the juxtaposition of specialized, quasi-specialized and non-specialized courts in the Member States discussed in the previous sections of this paper. Having said that, the aforementioned distinction should not be interpreted in an isolated manner but needs some respective comments. For example, considering the differences between commercial and specialized courts, it is very difficult to draw an unequivocal division. Even if commercial courts are not particularly specialized in the narrow, specific area of competition law or private antitrust enforcement, their understanding of economy and market-related issues really matters. The court's acquaintance of market structures, market rules, market indicators and market relations can 
significantly help when resolving antitrust litigations. Therefore, the distinction made in this chart is based on the subjective assessment and assumptions of the author. This is because very often it is hard to grasp the factual nature of a court, in particular the panel adjudicating antitrust cases. Therefore, the aforementioned distinction is debatable and the author is open for further discussion and possible changes of the qualification already made. As pointed out above, the chart should be always construed together with comments pertaining to the model of jurisdiction in a particular State.

Having in mind the results of this short study and considering its limitations too, it is very difficult to draw any clear conclusions with respect to the 'ideal' model of court in private antitrust cases. In the US, where antitrust litigations are developed the most, specialised courts dealing with antitrust actions have not been appointed. Indeed, the members of the panel, that is both the judge and the jury, do not possess extensive knowledge of either competition law or the economy. Nonetheless, as we can observe from the US antitrust litigation legacy, this characteristic does not disturb the great prospects of a plaintiff's success in litigation. As a result, the number of cases where the plaintiff was awarded damages is striking. For obvious reasons, expert witnesses are also necessary as well as the judges' practical experience, which plays an important role in litigations too.

Unlike the US example, the UK has both, a specialized court (the CAT) and a significant number of successful antitrust litigations. Even if the UK model is not an ideal one - assuming that it is not possible to set up any ideal model of court at all - it is certainly worth considering. This is in particular the case for those countries where private antitrust enforcement, even having implemented the Directive, is not developed enough. In the author's opinion, the British system could be a role model for some of them, Poland included. Paradoxically, in two other EU Member States with a significant number of antitrust litigations and very good prospects for their further development, no specialised court to resolve antitrust disputes has been established. These countries are the Netherlands and Germany. It is, however, worth noting that despite the lack of formal specialization, it is hard to question the factual specialization of German courts which arose out of good management within the judicial structure and procedure.

The model of jurisdiction in antitrust cases in the rest of the European States is not uniform, stretching between all types of courts mentioned in the chart below. Although the development of private antitrust enforcement differs among the States, neither of them experiences a significant number of antitrust litigations. For this reason, it is very difficult to build a causal link between the type of court and such development in a given State. The proportion of Member States with a specialised and quasi-specialized courts 
on the one hand and those having non-specialized courts on the other is fiftyfifty. In some cases of factual specialization, knowledge and expertise stem from practical experience in dealing with antitrust litigations.

When discussing the ideal model of court in private antitrust cases and judges' economic knowledge and experience, the findings from one of the studies conducted in this field are worthy of attention. The study is based on the US experience, where a non-specialised model of courts is used. Assuming that every antitrust litigation is a 'battle of the experts', the authors draw several interesting conclusions with respect to the relation between the economic training of judges and the appeal rate of a given court's decisions. Surprisingly enough, the results of the study show that in simple cases the economic training of judges can serve better quality of judgements, whereas in complex antitrust cases it does not help at all. Probably even more surprisingly, 'repeat exposure' to antitrust litigations, which stems from long practical experience of judges, does not significantly help either. As a consequence, only a combination of more advance economic training and the use of experts can serve better quality of judicial decisions (see Baye and Wright, 2010, p. 21-23). This is another factor that increases the complexity of the issue discussed in this paper.

\begin{tabular}{|l|l|l|l|}
\hline \multicolumn{1}{|c|}{ State } & Specialized & $\begin{array}{c}\text { Quasi-specialized } \\
\text { (commercial) }\end{array}$ & Non-specialized \\
\hline 1. USA & & & \\
\hline 2. UK & & & \\
\hline 3. Netherlands & & & \\
\hline 4. Germany & & & \\
\hline 5. Portugal & & & \\
\hline 6. Spain & & & \\
\hline 7. Italy & & & \\
\hline 8. France & & & \\
\hline 9. Austria & & & \\
\hline 10. Bulgaria & & & \\
\hline 11. Croatia & & & \\
\hline 12. Czech Rep. & & & \\
\hline 13. Estonia & & & \\
\hline 14. Hungary & & & \\
\hline 15. Poland & & & \\
\hline 16. Latvia & & & \\
\hline 17. Lithuania & & & \\
\hline 18. Romania & & & \\
\hline 19. Slovakia & & & \\
\hline 20. Slovenia & & & \\
\hline
\end{tabular}




\section{Closing remarks}

As mentioned above, the short study contained in this paper does not provide a satisfactory answer to the question about the ideal model of court that can be applied to handle antitrust damages claims. The main reasons for this conclusion were outlined in Section VII of this paper. One of the most important insights from it is the following. It is almost impossible to build causation between the type of court - whether specialised or not - and the development of private enforcement in a particular State. The American, British, German and Dutch examples, in juxtaposition with other EU Member States, is the most apparent example here. Nevertheless, it is also hard to question that the knowledge and experience of judges can have a positive effect when adjudicating private antitrust cases. This feature can be, in turn, the result of the same court reviewing decisions of the NCAs as well as deciding in antitrust litigations. The most characteristic, but not exclusive, example of this is the British CAT.

Having said that, in opinion of the author, the idea of specialized courts dealing with antitrust litigations should not be omitted, as it happened in some Member States, Poland included. The specialization of courts, either formal or at least factual ('repeat exposure') matters even if some authors are sceptical about this conclusion (Baye and Wright, 2010, p. 21-23). Therefore, particularly in countries aiming for a better development of antitrust litigations, the creation of a private antitrust litigation-specialized court should be seriously taken into consideration. The CAT can serve as a role model here, not meaning that it should be applied in its entirety since every State has its own legal specificity and culture.

For obvious reasons, a discussion of the model of jurisdiction competent in antitrust litigations cannot miss some elusive aspects, which affect the development of private antitrust enforcement too. One of them is the 'state of play' with respect to the litigation culture in a particular country. This can enhance, or not the development of antitrust litigations. Finally, it is worth emphasising that there are at least a few countries with a great private antitrust legacy and courts that handle antitrust litigations very well. As a consequence, those that do not have a similar experience can learn a lot from this legacy.

\section{Literature}

Adkins, B., Beighton, S. (2016). Private Antitrust Litigation in the UK (England and Wales): Overview, Thomson Reuters Practical Law. Retrieved from: https://uk.practicallaw. 
thomsonreuters.com/1-6331531?transitionType $=$ Default\&conte xt Data $=($ sc.Default $)$ $\&$ firstPage $=$ true $\&$ comp $=$ pluk \&bhcp $=1)(9.08 .2018)$.

American Bar Association, (2018). State Antitrust Enforcement Handbook.

Anastácio, G., Anastácio, C. (2018). Portugal. In: I.K.Gotts (ed.), The Private Competition Enforcement Review (Eleventh Edition, pp. 237-249). London: Law Business Research Ltd.

Barling, G. (2013). Competition litigation: what the next few years may hold, The David Vaughan CBE, QC/Clifford Chance Annual Lecture on Anti- Trust Litigation, 19 June 2013. Retrieved from: https://www.catribunal.org.uk/sites/default/files/2018-01/ Competition_litigation_what_the_next_few_years_may_hold_190613.pdf (9.08.2018).

Baye, M.R., Wright, J.D. (2010). Is Antitrust Too Complicated for Generalist Judges? The Impact of Economic Complexity \& Judicial Training on Appeals, Journal of Law and Economics, Vol. 54, No. 1 (February 2011), p. 1-24.

Bernatt, M. (2017), McWane and Judicial Review of Federal Trade Commission decisions - Any Inspirations for EU Competition Law? 38(6) European Competition Law Review 288 (2017).

Bernatt, M. (2016). The Effectiveness of Judicial Review in the Polish Competition Law System and the Place for Judicial Deference, Yearbook of Antitrust and Regulatory Studies, Vol. 9(14), 97-124.

Bernatt, M., Gac, M. (2017). Transposition of the EU Antitrust Damages Directive in Poland. In: B. Rodger, M. Sousa Ferro, F. Marcos (eds.), The EU Antitrust Damages Directive: Transposition in the Member States, Oxford University Press (forthcoming in 2019). Retrieved from: https://papers.ssrn.com/sol3/papers.cfm?abstract_id $=3006298$ (9.08.2018).

Blažo, O. (2017). Slovakia. In: A. Piszcz (ed.), Implementation of the EU Damages Directive in Central and Eastern European Countries (pp. 247-262). Warsaw: University of Warsaw Faculty of Management Press.

Broder, D.F. (2005). A Guide to US Antitrust Law. London: Sweet \& Maxwell.

Buntscheck, M., Stichweh, H. (2015). Germany: Private Antitrust Litigation, The European Antitrust Review, 154-158. Retrieved from: https://www.buntscheck.com/sites/default/ files/downloads/european-antitrust-review-2015.pdf (9.08.2018).

Butorac Malnar, V. (2017). Croatia. In: A. Piszcz (ed.), Implementation of the EU Damages Directive in Central and Eastern European Countries (pp. 55-84). Warsaw: University of Warsaw Faculty of Management Press.

Castronovo, C. (2007). Private Law Remedies in Antitrust Law Violations - A Point of View from Italy. In: Basedow, J. (ed.), Private Enforcement of EC Competition Law, Wolters Kluwer.

Competition Appeal Tribunal, Annual Report and Accounts 2016/2017. Retrieved from: http://www.catribunal.org.uk/ files/Annual_Report_16_17.pdf (9.08.2018).

Competition Litigation in France. Retrieved from: https://globalcompliancenews.com/ antitrust-and-competition/competition-litigation-in-france/ (9.08.2018).

Cornelissen, R., Dempsey, N., Knigge, A., Sluijter, P., VerLoren van Themaat, W. (2018). Netherlands. In: I.K.Gotts (ed.), The Private Competition Enforcement Review (Eleventh Edition, pp. 184-206). London: Law Business Research Ltd.

Crane, D.A. (2010). Optimizing Private Antitrust Enforcement, Vanderbilt Law Review 63, No. 2 (2010), pp. 675-723. 
De Ávila Ruiz-Peinado, F.R. (2016). Spanish Antitrust Private Enforcement: Enhancing Consumer Collective Redress. Working Paper IE Law School, AJ8-229-I, 20-01-2016, pp. 2-48.

Delgado, J., Perez-Asenjo, E. (2011). Economic evidence in private-enforcement competition law in Spain, European Competition Law Review, vol. 32/10 (2011).

Department for Business Innovation \& Skills (2016). Consultation: Implementing the EU Directive on damages for breaches of competition law. Retrieved from: https://assets. publishing.service.gov.uk/government/uploads/system/uploads/attachment_data/ file/495757/BIS-16-6-consultation-implementing-the-EU-directive-on-damages-forbreaches-of-competition-law.pdf (9.08.2018).

De Sousa e Alvim, M. (2017). A Brief Review of the Implementation of the EU Antitrust Damages Directive in Portugal. Global Competition Litigation Review, Issue 4, pp. 212-215.

Elsner, B., Zandler, D. Kos, M. (2018). Austria. In: I.K.Gotts (ed.), The Private Competition Enforcement Review (Eleventh Edition, pp. 41-50). London: Law Business Research Ltd.

Freeman, P. (2016). Better to travel hopefully than to arrive? The Reform of UK Competition Law 1991-2016, Regulatory Policy Institute 25th Anniversary Conference, Merton College Oxford 12th/13th September 2016. Retrieved from: http://www.catribunal. org.uk/files/The\%20Reform\%20of\%20UK\%20Competition\%20 Law\%201991-2016. pdf (9.08.2018).

Gelmini, F. (2017). Brexit: The Future of Private Antitrust Enforcement in the UK, 20 December 2017. Retrieved from: https://www.europeanfutures.ed.ac.uk/article-5714 (9.08.2018).

Gotts, I.K. (2018). Preface. In: I.K. Gotts (ed.), The Private Competition Enforcement Review (Eleventh Edition, pp. vii-xi). London: Law Business Research Ltd.

Gutiérrez, A., Arranz, T. (2018). Spain. In: I.K. Gotts (ed.), The Private Competition Enforcement Review (Eleventh Edition, pp. 277-289). London: Law Business Research Ltd.

Hovenkamp, H. (2005). Antitrust, Thomson/West.

Idot, L. (2007). Private Enforcement of Competition Law - Recommendation Flowing from the French Experience. In: Basedow, J. (ed.), Private Enforcement of EC Competition Law, Wolters Kluwer.

Ion, M., Ambrozie, L., Nistor, V. (2018). Romania. In: I.K. Gotts (ed.), The Private Competition Enforcement Review (Eleventh Edition, pp. 250-260). London: Law Business Research Ltd.

Jerneva, J., Druviete, I. (2017). Latvia. In: A. Piszcz (ed.), Implementation of the EU Damages Directive in Central and Eastern European Countries (pp. 157-178). Warsaw: University of Warsaw Faculty of Management Press.

Jones, C.A. (1999). Private enforcement of antitrust law in the EU, UK and USA. New York: Oxford University Press.

Jurkowska, A. (2008). Antitrust Private Enforcement - Case of Poland. Yearbook of Antitrust and Regulatory Studies, Vol. 2008, 1(1), 59-79.

Jurkowska-Gomułka, A. (2013). Publiczne i prywatne egzekwowanie zakazów praktyk ograniczających konkurencję. Warszawa: Wydawnictwo Naukowe Wydziału Zarządzania Uniwersytetu Warszawskiego. 
Kuijpers, M., Tuinenga, S., Wiskin, S., Dietzel, K., Campbell, S., Fritzsche, A. (2015). Actions for Damages in the Netherlands, the United Kingdom, and Germany. Journal of European Competition Law \& Practice, Volume 6, Issue 2, 1 February 2015, 129-142, https://doi.org/10.1093/jeclap/lpu125.

Laguna de Paz, J.C. (2012). Judicial Review in European Competition Law, 1-30. Retrieved from: https://www.law.ox.ac.uk/sites/files/oxlaw/judicial_review_in_european_ competition_law.pdf (9.08.2018).

Lande, R.H., Davis, J.P., (2008). Benefits From Private Antitrust Enforcement: An Analysis of Forty Cases. University of San Francisco Law Review, Vol. 42, Iss. 4, 879-918.

Lande R.H. (2006). Five Myths About Antitrust Damages. University of San Francisco Law Review, Vol. 40, p. 651.

Lande, R.H. (2004). Why Antitrust Damage Levels Should Be Raised. Loyola Consumer Law Review, Vol. 16, No. 4, 329-345.

Leeflang, F., Kuijper, M. (2013). Netherlands. Private Antitrust Litigation, Global Competition Review.

Marcos, F. (2013). Competition Law Private Litigation in The Spanish Courts (1999-2012). Working Paper IE Law School AJ8-202. Retrieved from: https://papers.ssrn.com/sol3/ papers.cfm?abstract_id=2351770 (9.08.2018).

McAfee, R.P., Vakkur, N.V. (2004). The Strategic Abuse of the Antitrust Laws. Journal of Strategic Management Education 1(3). Retrieved from: https://vita.mcafee.cc/PDF/ strategicantitrust.pdf (9.08.2018).

Merril, T.W. (2010). The Origins of the American-style judicial review. In: S. Rose-Ackerman, P.L. Lindseth (eds.), Comparative Administrative Law. Edward Elgar Publishing Limited.

Mikelènas, V., Zaščiurinskaitè, R. (2018). Lithuania. In: A. Piszcz (ed.), Implementation of the EU Damages Directive in Central and Eastern European Countries (pp. 179-210). Warsaw: University of Warsaw Faculty of Management Press.

Mircea, V. (2017). Romania. In: A. Piszcz (ed.), Implementation of the EU Damages Directive in Central and Eastern European Countries (pp. 237-246). Warsaw: University of Warsaw Faculty of Management Press.

Miskolczi Bodnár, P. (2017). Hungary. In: A. Piszcz (ed.), Implementation of the EU Damages Directive in Central and Eastern European Countries (pp. 127-156). Warsaw: University of Warsaw Faculty of Management Press.

Nazzini, R. (2015). The Effect of Decisions by Competition Authorities in the European Union. Italian Antitrust Review, No. 2 (2015), 68-97, DOI: 10.12870/iar-11577.

Oster, T. (2018). France. In: I.K.Gotts (ed.), The Private Competition Enforcement Review (Eleventh Edition, pp. 100-108). London: Law Business Research Ltd.

Pärn-Lee, E. (2017). Estonia. In: A. Piszcz (ed.), Implementation of the EU Damages Directive in Central and Eastern European Countries (pp. 109-125). Warsaw: University of Warsaw Faculty of Management Press.

Petit, N. (2009). Judicial Review in French Competition Law and Economic Regulation: A Post Commission v. Tetra Laval Assessment. In: O. Essens, A. Gerbrandy, S. Lavrijssen (eds.), National Courts and the Standard of Review in Competition Law and Economic Regulation (pp. 103-125). Amsterdam: Europa Law Publishing.

Petr, M. (2017). Czech Republic. In: A. Piszcz (ed.), Implementation of the EU Damages Directive in Central and Eastern European Countries (pp. 85-108). Warsaw: University of Warsaw Faculty of Management Press. 
Petrov, A. (2017). Bulgaria. In: A. Piszcz (ed.), Implementation of the EU Damages Directive in Central and Eastern European Countries (pp. 25-54). Warsaw: University of Warsaw Faculty of Management Press.

Peyer, S. (2010). Myths and Untold Stories - Private Antitrust Enforcement in Germany. Centre for Competition Policy Working Paper No. 10-12. Retrieved from: https:// ueaeprints.uea.ac.uk/29237/1/Peyer_-_Myths_and_Untold_Stories-Private_Anti trust_ Enforcement_in_Germany.pdf (02.09.2016).

Piszcz, A., Wolski, D. (2017). Poland. In: A. Piszcz (ed.), Implementation of the EU Damages Directive in Central and Eastern European Countries (pp. 211-236). Warsaw: University of Warsaw Faculty of Management Press.

Raffaelli, E.A. (2018). Italy. In: I.K.Gotts (ed.), The Private Competition Enforcement Review (Eleventh Edition, pp. 165-175). London: Law Business Research Ltd.

Reger, A. (2018). Reflections on the decision of the Competition Appeal Tribunal in Pfizer/Flynn. Kluwer Competition Law Blog, June 21 2018. Retrieved from: http:// competitionlawblog.kluwercompetitionlaw.com/2018/06/21/reflections-decisi on-competition-appeal-tribunal-pfizerflynn/ (9.08.2018).

Robertson, A. (2017). UK: Competition Damages Litigation In London Pre - And PostBrexit. Funding in Focus, Issue 4, 2017, 34-39. Retrieved from: https://www.vannin.com/ downloads/funding-in-focus-four.pdf (9.08.2018).

Saint-Antoine, P.H., Lewers, J.C., Hutchison, T.N., Bullard, K.P., Michelen, L.B. (2016).

Private antitrust litigation in the United States: overview. Retrieved from: https://content. next.westlaw.com/Document/I723cf4636e4e11e698dc8b09b4f043e0/View/FullText. html contextData $=($ sc.. efault $) \&$ transitionType $=$ Default $\&$ firstPage $=$ true $\& b h c p=1$ (9.08.2018).

Slaughter and May (2017). Private enforcement of competition law in the UK, August 2017. Retrieved from: https://www.slaughterandmay.com/media/2534704/privateenforcement-of-competition-law-in-the-uk.pdf (9.08.2018).

Sullivan, E.T., Hovenkamp, H. (2003). Antitrust law, policy and procedure: cases, materials, problems. Lexis Nexis.

Sullivan, L.A., Grimes, W.S. (2006). The Law of Antitrust: An Integrated Handbook. West Academic Publishing.

Tardella, E., Maggiore, M., Italy, Ashurst. Retrieved from: http://ec.europa.eu/competitio n/antitrust/actionsdamages/national_reports/italy_en.pdf (9.08.2018).

Toffoletti, L., De Stefano, A. (2018). Private antitrust litigation in Italy: overview, 1 May 2018. Retrieved from: https://uk.practicallaw.thomsonreuters.com/1-633-4469?transiti onType $=$ Default $\&$ contextData $=($ sc.Default $) \&$ firstPage $=$ true $\&$ comp $=$ pluk $\& b h c p=1$ (9.08.2018).

VerLoren van Themaat, Hettema, W., Buruma, J.H. (2004). Netherlands. Ashurst. Retrieved from: http://ec.europa.eu/competition/antitrust/actionsdamages/national _reports/netherlands_en.pdf (02.09.2016).

Vlahek, A., Podobnik, K. (2017). Slovenia. In: A. Piszcz (ed.), Implementation of the EU Damages Directive in Central and Eastern European Countries (pp. 263-296). Warsaw: University of Warsaw Faculty of Management Press.

Wach, K., Epping, M., Zinsmeister, U., Bonacker, E. (2004). Germany. Ashurst. Retrieved from: http://ec.europa.eu/competition/antitrust/actionsdamages/national_reports/ germany_en.pdf (02.09.2016). 
Wils, W.P.J. (2003). Should Private Antitrust Enforcement Be Encouraged in Europe? World Competition, Volume 26, Issue 3, September 2003, 473-488.

Zhang, A.H., Liu, J., Garoupa, N. (2017). Judging in Europe: Do Legal Traditions Matter? Journal of Competition Law \& Economics (forthcoming). Retrieved from: https://papers. ssrn.com/sol3/papers.cfm?abstract_id=3082854 (9.08.2018).

Zuehlke, S., (2018). Germany. In: I.K.K.Gotts (ed.), The Private Competition Enforcement Review (Eleventh Edition, pp. 109-121). London: Law Business Research Ltd. 